\title{
USE OF SYSTEM ANALYSIS IN LAW, AS THE CORE OF THE ANALYTICAL PROCESS OF INFORMATION PROCESSING
}

\section{Zaiets O.M.}

\section{INTRODUCTION}

The result of the political and socio-economic transformations that are taking place in the world today are the dynamic changes in the functioning of states and existing and emerging international unions. The current situation creates the circumstances for the emergence and development of new forms of crime and criminal phenomena. Organized crime has gained unknown to this time, and the most dangerous and complex forms, has become one of the main causes of the global decline in the sense of security. The conditions that have emerged have identified new requirements in the application of modern technologies for detecting offenses and making decisions in the course of law enforcement activities.

To overcome regional and transnational crime, law enforcement agencies from developed countries (France, USA, UK, Romania, Poland) criminal intelligence and risk management are used as key instruments for national security.

Based on the assessments of institutions that criminal analysis is used in their daily activities, it can undeniably be asserted that it is an effective tool for combating crime.

Given that the criminal analysis system is characterized by identical analytical procedures and principles and symbols of visual representation, it is a kind of international interpretation of criminal events by criminal analysts around the world. This indisputable argument also creates new opportunities for the development of effective cooperation and cooperation between national and international law enforcement agencies.

The essence of each analysis lies in the process of methodological identification of the links between any information, which leads to the formulation of the answer to the question: what, why? and what for? When it comes to criminal analysis, its essence is a clear statement of 
reasoning and proposals for further action aimed at apprehending offenders and detecting evidence of a crime.

The system for analyzing information in the activities of law enforcement bodies is to establish and search for links between data on criminal activity and other data potentially associated with them for the purpose of their use in the development of tactical and strategic principles, including in the area of integrated border management, which is based on the analysis of information and aimed at cooperation, as well as finding solutions to the fight against organized crime, nationally and internationally.

Established in the law enforcement agencies of the information analysis system, they have become adequate mechanisms for combating crime, an instrument for creating an integrated risk management system, providing information and analytical support, preparing management decisions and a means of preventing the response to existing threats in the area of national security.

\section{General directions of analytical activity of law enforcement bodies for protection of economic rights, freedoms and interests of persons during investigation of criminal offenses}

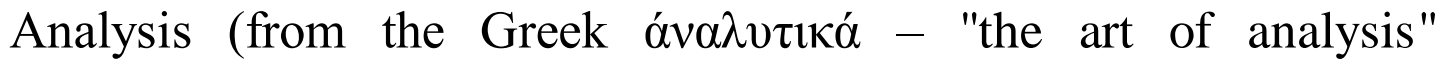
decomposed) are those parts of the philosophical systems in which the objects of philosophy are decomposed into constituent elements so that then it is possible, on the basis of them, to make unmistakable conclusions and applications.

The process of cognition is a complex whole, from which no element can be removed, so that the whole process does not come into disarray. We get knowledge from different sources: art, religion, and philosophy can be alongside with science. Undoubtedly, the character of thinking analyst and analyst as a system of knowledge should be dialectical. Naturally, the perception of reality by any person is carried out subjectively. However, the main thing is that a reasonable person should maximally strive for the objectivity and adequacy of reflection of reality, to develop their mental faculties, using for this all the richness of dialectical methodology.

The role of intelligence at all times and in all countries was extremely high. Intellect is the most valuable resource and product owned by a society that seeks to develop. 
It is well-known that in modern conditions, the intellectual resource of the population as well as the demographic, territorial, raw material, technological parameters of a society is the most important condition for progressive development. Moreover, it can be affirmed that without the active involvement of this resource, other resources work only partially. The intellect has one unique property - self-reproduction. The more it is used, the more it becomes. And another unique property of intelligence it multiplies the available material resources.

The philosophical category "system" is extremely important for analytics. Like motion, space, time, the reflection of systemicity is a concept that reflects the general, inalienable properties of matter. The system captures the predominance of organization in the world over chaotic changes. The unauthorized change in one in any respect turns out to be orderly in another. Organisativity is inherent in matter in any of its spatio-temporal scales and finds its theoretical explanation and reflection in the category "system".

From the point of view of philosophy, the content of system analysis as the nucleus of analysts gives practitioners the opportunity to increase the efficiency of their work, the main idea of system analysis is the combination of formal and informal representations in models and methods that help gradually to formalize the ways of objective reflection and analysis of the problem situation, to reveal its essence.

The place of system analysis in the structure of analytics and related branches of knowledge is presented in Figure 1.

While conducting a system analysis, it is necessary, first of all, to reflect the situation with the help of the fullest possible definition of the system, and then, highlighting the most significant components that influence the decision-making, to formulate a working definition of the system, which can be specified, expand or narrowing, depending on the analysis process .

Owning a method of system analysis largely determines the level of professionalism of the analyst.

The concept of system analysis is by no means a concept associated exclusively with military systems or security systems. It is a means of finding solutions to resolve contradictions in any problem area. The objective characteristic, the identification and formulation of the problem involves its solution, which uses the entire analytical arsenal of information processing techniques. Accordingly, the necessary 
approaches to choosing a strategy that gives the best ratio of risk, efficiency and cost.

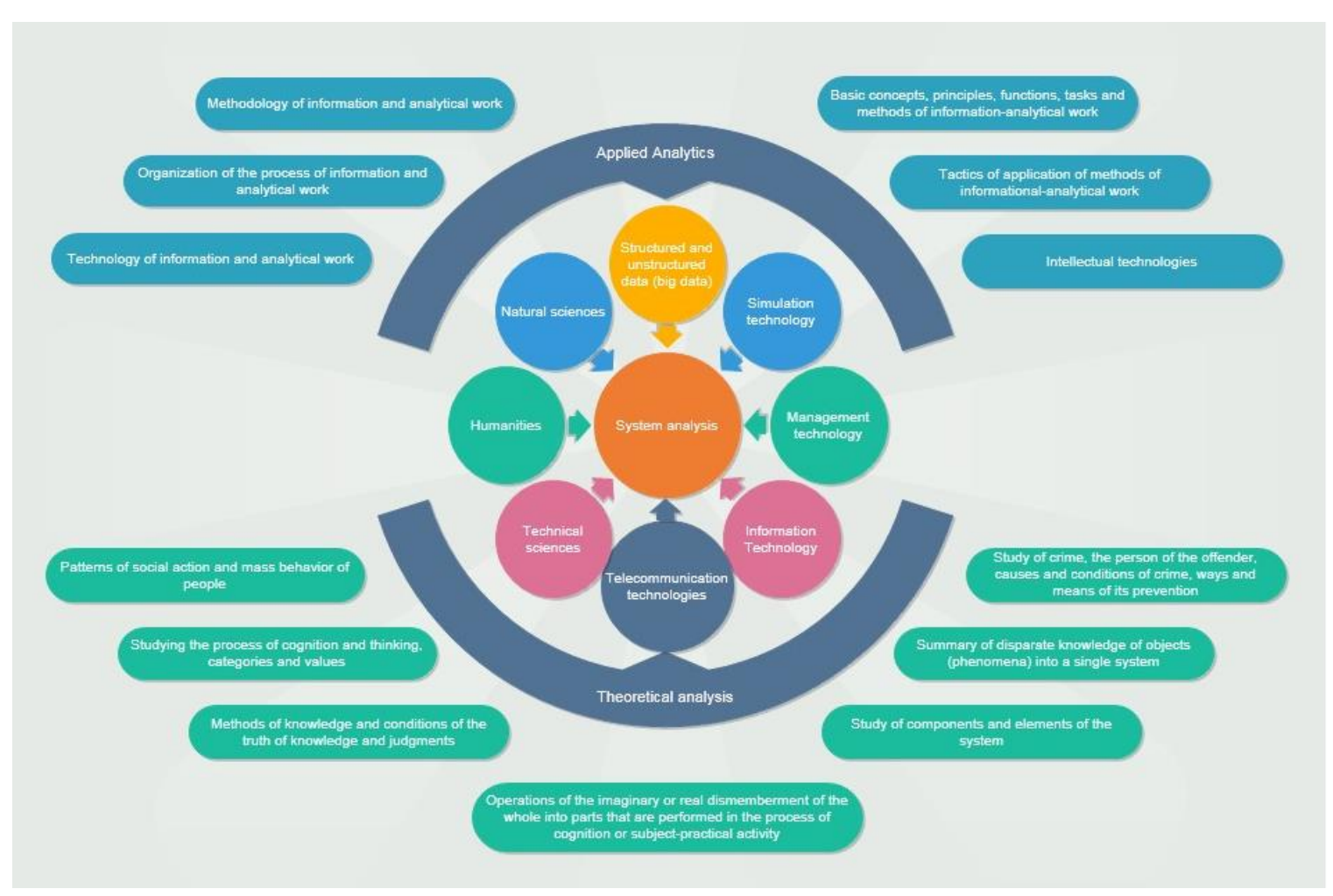

Fig. 1

The purpose of the system analysis by examining each element of the system in its own environment is to ensure that the system as a whole can fulfill its task at a minimal cost of resources.

The main thing in the system analysis is how difficult it is to turn into a simple; in search of effective means of managing complex objects; as difficult-to-understand problem to optimize in a series of tasks, in principle have a solution, to show their structure and hierarchy, the sequence of actions.

Thus, system analysis is a complex, multifactor approach to the consideration of objects of analysis, their representation as a system that has its elements, relationships, structure, functions. It is very important to understand that system analysis is not a formal method of analysis based on frozen dogma, but rather a conceptual approach that requires the creative use of the maximum range of disciplines and research methods for systematic consideration of any one problem. 
Within the framework of the given powers, law enforcement agencies obtain a sufficient array of information on criminal activity, including organized crime. In connection with the above, the overriding task is the use of tools that would enable the processing of a large amount of available data. One such instrument is a criminal analysis ${ }^{1}$.

In the countries of the European Union, the USA and other developed countries, the use of criminal analysis capabilities is mandatory for all law enforcement agencies. Its content, rules and procedures are clearly defined and regulated in a legal sense. This, in particular, concerns the conduct of operational search activities, pre-trial investigations and criminal proceedings in court ${ }^{2}$.

Criminal analysis is a specific type of information-analytical activity that is to identify and, as accurately as possible, determine the internal relationships between information (information, data) relating to a crime and any other data obtained from different sources, their use in the interests of conducting investigative and investigative activities, their analytical support ${ }^{3}$.

In the course of criminal analysis, targeted search, detection, fixation, deletion, organizing, analysis and evaluation of criminal information, its representation (visualization), transmission and realization are provided.

In the process of criminal analysis the following main types operational (operational), tactical and strategic are distinguished ${ }^{4}$.

Operational (analytical) analytics is aimed at a short-term law enforcement action or an active case that serves to achieve within a short time the intended purpose in the form of, for example, arresting and arresting a suspect, imposing an arrest on a crime instrument or extracting it.

${ }^{1}$ Користін О.С., Албул С.В. та ін. Основи кримінального аналізу : посібник з елементами тренінгу. Одеса : ОДУВС, 2016 С. 9.

2 Албул С.В. Кримінальна розвідка як функція оперативно-розшукової діяльності: Європейський досвід та Українські перспективи. European Reforms Bulletin: international scientific peer-reviewed journal: Grand Duchy of Luxembourg. 2015. № 2. C. 2.

${ }^{3}$ Власюк О.В. Роль і місце кримінального аналізу у розкритті та розслідуванні злочинів на державному кордоні України. Матеріали постійно діючого науковопрактичного семінару. Х. : Інститут підготовки юрид. кадрів для СБУ Нац. юрид. акад. Украӥни ім. Я. Мудрого, 2011. Випуск № 3. Частина № 1. С. 82.

${ }^{4}$ Користін О.С., Албул С.В. та ін. Основи кримінального аналізу : посібник 3 елементами тренінгу. Одеса : ОДУВС, 2016 С.9. 
The operational (operational) analysis is directed directly at the analytical support of operative and investigative activities, in particular as part of the work on operational searches, as well as analytical support for pre-trial investigation of criminal offenses, the conduct of which falls within the competence of the bodies of the National Police of Ukraine. In addition, the results of operational criminal analysis are passed on to other law enforcement authorities, along with the data (information) of the detected offenses.

Operational (criminal) analysis consists of planning, collecting, collecting, comparing and evaluating information for its analysis and reporting as well as further setting of tasks.

The purpose of collecting and analyzing information is to create and test hypotheses and conclusions about past, present and future wrongful acts, including the description of the structure and scope of criminal groups and the transfer of the leading components of clear information concerning operational searches and investigative search actions.

Operational (criminal) analysis is carried out in three forms:

1. The analysis accompanying the operational search and investigative activities (the available information related to the proceedings is streamlined, the new information is correlated and evaluated accordingly, hypotheses that are supported by evidence or conclusions are refuted in the current order).

2. Analysis that is conducted to support investigative and investigative activities (the analyst takes on analytical tasks, presents the results of the analysis, searches for information from his own databases).

3. Analysis that initiates operational search and investigative activities.

All forms of analysis are interlinked, if the analysis is accompanied by operational search and investigative activities, at the same time it supports it and gives grounds for conducting investigative (search) actions and operational-search activities. In the course of the analytical process, information about the offender, the course of the event, the means of committing a crime, the time and place of his commission, etc. are evaluated. The circulation of this information occurs between operational staff and investigators, which consists not only in the provision or receipt of information, but also in the active acquisition of information. 
The source of information may be the database, materials of pretrial investigations, including protocols for interrogations of witnesses and suspects, materials of operative and prosecution cases, reports of other bodies, media reports, etc.

The practical use of criminal analysis by the operative-search units of the National Police of Ukraine confirmed its high efficiency in multiepisode proceedings covering a large area, including a significant number of events and subjects of a criminal group with a complex structural structure. In these cases, traditional methods of tracking and asserting facts were not effective enough.

Operational criminal analysis can cover the following areas: crime, criminals and methods of doing business.

Crime analysis is to reconstruct its course by establishing a sequence of individual events; presence of signs of repetition of events; the mutual disconnection of information originating from various sources. The analysis of the crime is carried out with the purpose of determining recommendations for further direction of conducting operational-search activities and investigative (search) actions.

In the process of crime analysis, various analytical technologies are used, including action schemes, event schemes or activity schemes.

In addition to analyzing a crime, a comparative analysis of crimes can be performed, which is to compare information on criminal proceedings against similar crimes, in order to determine whether some of them could be committed or organized by the same suspect. In conducting comparative analysis of crimes, analytical technologies such as systematic search in databases, review of reports and reports, comparison of similarity of the obtained data and determination of the likelihood of this similarity are used.

An analysis whose subject matter is a criminal may relate to a criminal group or a specific offender's profile. Analysis of the criminal group consists in organizing information on the members of the criminal group in order to get acquainted with the structure of the group and the establishment of the roles of its individual members. In conducting criminal group analysis, analytical technologies such as interconnection schemes, action plans, event schemes, activity diagrams, telephone call analysis, financial transaction analysis and financial profiling of individuals involved in criminal proceedings are used. The analysis of the psychological profile of the typical perpetrator makes it possible to 
determine on the basis of the description of the crime, the character of the person who committed it, the type of person-perpetrator, the possible area of his residence, the work performed.

Strategic analytics deals with longer-term problems and challenges such as identifying key criminal individuals or criminal syndicates; forecasts of the growth of criminal activity and the establishment of priorities in law enforcement activities.

Strategic Criminal Analysis focuses on data processing for management processes and decision making. Information, depending on the recipient, has a planning, evaluation, guidance or controlling character. Its subject is the long-term goals, definition of priorities and strategies for combating crime on the basis of in-depth research and forecasting its development.

The products of strategic analysis, as a rule, are: reports on the situation; analyzes of phenomena; thematic analyzes; criminological regional analyzes; structural analysis of threats; Concepts / proposals for improving the fight against crime.

During the analysis of crime an analysis of its essence, volume, dynamics and development of crime or its various types (categories of crimes) in separate territories and for a certain period of time is carried out. The results of this analysis can be presented in the following analytical forms: charts, graphs, tables, diagrams, maps, photos, geolocation, statistical information, written reports, etc.

The aggregate of the evidence collected as a result of these acts creates, at the initial stage of the pre-trial investigation of criminal proceedings, sufficient prerequisites for the information provision of the further course of the investigation. However, this becomes possible only when these actions are carried out taking into account all the peculiarities of the search-and-cognitive activity of the investigator and the peculiarity of the information display of the crime event.

Consequently, the main objective of criminal analysis is to strengthen mechanisms for the prevention, detection, documentation and investigation of criminal offenses, as well as the establishment of mechanisms for monitoring the crime situation, the exchange of information at the state, regional and international levels regarding trends and risks in this area. 


\section{Use of elements of criminal analysis during the investigation of economic criminal offenses}

Currently, in most countries of the world, elements of criminal analysis are used to process large-scale information arrays, as well as visualize the circumstances of events, connections between individuals, events and individuals during the investigation of economic criminal offenses, which are often latent, well-organized and subject to actors management of a large amount of damage. In addition, elements of criminal analysis help to make the right procedural and organizational decisions, and prevent a number of possible negative consequences during the investigation of economic criminal offenses. Thus, criminal analysis data that is timely (that is, the information is provided on time) provide grounds for taking measures (this definition implies that the information is sufficiently detailed and reliable for carrying out the appropriate measures) necessary for the effective conduct of investigators (investigators) and other procedural actions in the investigation of serious and especially grave economic crimes and other illegal activities of organized crime, especially if it has a transnational character.

A characteristic feature of modern economic crimes is the availability of a large amount of information that was obtained by operational or investigative means, which should be generalized, processed, analyzed, and assessed and further used effectively in investigations of the specified crime category. For this purpose, it is necessary to actively use analytical methods recognized in many developed countries of the world.

The analysis is a methodology that seeks to establish the presence of a link or link between two or more elements of forensically meaningful information. The analysis allows you to remove relevant information and use it to reduce the degree of uncertainty and predict what can happen with a certain probability, to make logical, rational and substantiated conclusions in criminal proceedings.

Significant role in the implementation of criminal analysis of the leading countries of the world is its information support. At present, powerful information arrays are created and integrated in different areas of activity, which allows for effective investigation of criminal offenses. One of the leaders in the software for criminal analysis is IBM. Thus, the use of the IBM I2 Analyst's Notebook software facilitates the accumulation, processing, research and use of available data on a criminal offense committed, and thus positively affects the effectiveness 
of the investigation of criminal proceedings. The IBM I2 Analyst's Notebook is a visual analytical environment that maximizes the use of enormous amounts of information accumulated by public services and enterprises. With an intuitive context-based interface, analysts (operational staff, investigators and other law enforcement officers) can quickly collate, analyze, and visualize data from different sources, reducing the time to find important information in complex data.

The IBM I2 software is a direct-purpose computer software designed to summarize, analyze, proxy, and visualize real-time information exchange. This software is a set of interoperable programs that perform the relevant specific functions at all stages of the crime investigation. The specified software product is an advanced method of investigation of crimes and analysis of operational information.

The IBM I2 Analyst's Notebook helps law enforcement agencies to solve the following tasks:

- to systematize structured and unstructured data from many sources into a single coherent presentation;

- to identify key persons (persons involved in criminal proceedings), events, relationships and regularities between them, which can not always be detected by other means;

- to improve understanding of the structure, hierarchy and methods of action of criminal groups specializing in committing economic crimes;

- to facilitate the exchange of complex data, which allows to receive timely and effective operational and tactical decisions in the course of criminal proceedings;

- the ability to benefit from rapid implementation, which ensures rapid growth of productivity, thanks to reliable solutions for visual analytics;

- import various types of data, including phone call records, financial transactions, IP address logs and forensic research on mobile phones;

- Convert data in a clear and understandable way, which helps to analyze complex scenarios;

- effectively analyze a wide range of data types using a flexible data modeling and visualization environment;

- Detailed analysis and deep understanding of the data through various analytical representations, including associative, spatial, temporal and statistical representations; 
- operative definition of key persons, relationships between them and their connection with key events using the functions of analysis of the main connections;

- understanding of the main stages of the development of events or regularities in criminal activity at the expense of powerful tools for conducting time analysis;

- to identify possible mediators between, at first sight, unrelated entities in the network;

- the possibility to study data in detail in order to identify unobvious connections, patterns and trends in complex data;

- geospatial analytics capabilities;

- use integrated analysis of social networks to identify key individuals and relationships within criminal organizations;

- to assist in the decision making process and optimize the use of resources for rapid response to network penetration, surveillance or violation of their work;

- creation of intuitive diagrams, in which the supporting data for briefings and presentations are fixed and systematized;

- integration of information and visual representation of data into analytical reports;

- the ability to share charts with people who do not use I2 Analyst's Notebook ${ }^{5}$.

These features are inherent in many similar software products. Therefore, their use will only positively affect the completeness and speed of the investigation of economic crime.

The use of analytical programs in data analysis provides a number of positive factors that help to increase the efficiency and effectiveness of the actors of evidence.

Therefore, the use of the above-mentioned methods and software products in the investigation of crimes related to unlawful benefits,

${ }^{5}$ Beebe, Sarah Miller; Pherson, Randolph H. (2014). Cases in Intelligence Analysis: Structured Analytic Techniques in Action. SAGE Publications; Heuer, Richards J. Jr. (2007). Psychology Intelligence Analysis, Pherson Associates, LLC: Reston, VA. URL: https://www.cia.gov/csi/books/19104/ index.html; Pherson Katherine and Pherson Randolph. (2013) Critical Thinking for Strategic Intelligence. SAGE Publications. Central Intelligence Agency (CIA); Khalsa, S. (2009). Intelligence Community Debate over Intuition versus Structured Technique: Implications for Improving Intelligence Warning. Journal Confli. Studies. Retrieved from http://journals.hil.unb.ca/index.php/JCS/article/ view/15234/20838; A Tradecraft Primer: Structured Analytic Techniques for Improving Intelligence Analysis, 2012 - Cognitive and Perceptual Biases, Reasoning Processes. 
which will provide the relevant investigators and operational units with a number of significant advantages, seems to be justified: 1) the construction of informative schemes of criminal and family ties of individuals and suspects; 2) construction of schemes of criminal ties in the scale of the rayon, city, region and the whole state; 3) reliable identification of new entrants subject to operational development; 4) determining the distribution of roles among members of criminal groups; 5) the establishment of new members of criminal groups; 6) effective documentation and investigation of multi-episode crimes; 7) reflection of the directions of traffic flows of money caught in a criminal way, and their further legalization; 8) forecasting of possible conflicts of interest among civil servants; 9) coherence of actions of participants of the investigation and operational group; 10) presentation of the results of law enforcement activities ${ }^{6}$.

For example, a solution to the problem of determining the distribution of roles among members of criminal groups that commit economic crimes can be considered through phone analysis and computer analysis. With the help of this analysis, evidence can be obtained, which is concealed by criminals, is carefully guarded against leakage and distribution.

This information can be used to successfully plan further conduct of investigative (investigative) actions, as well as to effectively organize the investigation of criminal proceedings in general.

Criminal analysis of telephones consists of a vowel and anonymous conduction with the use of appropriate technical means for observing, selecting and fixing the content of information transmitted by a person, as well as receiving, converting and fixing various types of signals transmitted by communication channels (signs, signals, written text , images, sounds, messages of any kind $)^{7}$. By analyzing a person's telephone, which is of interest to law enforcement agencies, it is possible

${ }^{6}$ Сайтбеков А.М., Кондратьев И.В. Возможности использования аналитических программ в борьбе с организованной преступностью. Вестник КарГу. 2015. URL: http://articlekz.com/article/11838. Холостенко А.В. Можливості використання аналітичних методик при розслідуванні злочинів, повьязаних із неправомірною вигодою. Кримінальна розвідка: методологія, законодавство, зарубіжний досвід: матеріали Міжнародної науково-практичної конферениії (м. Одеса, 29 квітня 2016 р.). Одеса: ОДУВС, 2016. С. 175.

${ }^{7}$ Інструкиія про організачію проведення негласних слідчо-розшукових діü. URL: http://zakon3.rada.gov.ua/laws/show/v0114900-12. 
to monitor its telephone conversations and other signals such as: SMS, MMS, fax, modem communications, which are transmitted through the telephone communication channel being controlled ${ }^{8}$.

In the future, information from phones and computers is analyzed, and the findings of criminal analysts about determining the distribution of roles between members of criminal groups are visualized to facilitate perception.

Visualization of the circumstances of events, connections between individuals, events and individuals is an important part of the use of elements of criminal analysis during the investigation of economic criminal offenses. This is confirmed by the fact that law enforcement agencies in the United States and a number of European countries place considerable emphasis on such visualization, in particular when developing relationships between persons who are of operational interest or are involved in criminal proceedings. As practice shows, during the conduct of criminal intelligence, visualized information is much better perceived by law enforcement officers, which in turn increases the effectiveness of their activities ${ }^{9}$.

Processing large amounts of information is possible only with the use of intelligent technologies, such as IBM I2, which reduce the brain load of the investigator and help him when making a decision in the investigation of complex ephemeral economic crimes.

The analysis of democratic socio-political, economic, legal and organizational measures for the restructuring of society in Ukraine suggests that the state authorities seek to counteract the negative trends of social development, their intellectual and organizational potential, and change the situation for the better. First of all, it concerns the fight against economic crime. Determinants of the growth of crime and the criminalization of social relations are not only in themselves negative socio-economic factors of social development, but also the inability to counteract these factors of a balanced state economic, social and legal policy and to ensure the proper legal order of regulation of social

8 Албул С.В. Злочинне середовище та його інфраструктура як об'єкти реалізації розвідувальної функції оперативно-розшукової діяльності органів внутрішніх справ. Процесуальні, криміналістичні та психологічні аспекти досудового розслідування: Матеріали Всеукраїнської науково-практичної конферениії (Одеса, 07 листопада 2014). Одеса: ОДУВС, 2014. С. 29-30.

Бандурка О. М., Перепелиця М.М., Манжай О. В. Оперативно-розшукова компаративістика: [монографія]. Харків: ХНУВС, 2013. С. 83. 
relations. Therefore, for Ukraine, it is important to involve foreign experience in combating economic crime.

Economic crime is becoming an increasingly problematic, threatening phenomenon for Ukraine as an independent, independent and young sovereign state. Existing for a long time, imperfect economic relations are used by criminals to parasitize the body of a society, to provide significant material revenues at the expense of non-payment of taxes, corruption, fraud with financial resources, legalization by means of "money laundering" of money laundered, occupation of prohibited types of economic activity, direct encroachment on all forms of property and committing other crimes of economic orientation. Obviously, such acts should not be left without proper response from the state; they oblige their law enforcement agencies to fight uncompromisingly with them. The current state of state-building in Ukraine is closely linked with the development of foreign experience in public administration in the organization of law enforcement activities, including the fight against crime in the field of economic relations, because economic crime has grave consequences for any society. By choosing the path to improving and developing the system of law enforcement, it is always useful to really evaluate your own experience and, at the same time, turn to the developments in this field of scientists from other countries. A scientific study shows that foreign states are different socio-political entities with their own history, peculiarities of the state system, political system, culture and traditions. Therefore, consideration of foreign experience needs to be generalized, choosing from this experience the most significant elements, characteristics, trends that make up scientific and practical interest for Ukraine.

The US experience in combating legalization (laundering) of criminal profits proves the following. In the United States, the legal definition of the legalization of criminal proceeds was expanded, and now the crime is recognized by the conduct of the operation itself with funds of doubtful origin, regardless of the fact of proving a predicate crime. Criminal liability for the legalization of criminal proceeds in the United States is established both at the federal level and in each individual state. A separate responsibility for the establishment and for the so-called "structuring" - the distribution of a large amount of money for small amounts in order to avoid checks by the government. Such activity is regarded as misleading in order to conceal suspicious 
transactions ${ }^{10}$. Since the legalization of criminal proceeds consists in the implementation of any cash operations, countering the legalization is, first of all, in tracking cash flows and cashless funds. One of the most effective ways of tracking cash flow is monitoring payments.

Today, in the United States, the two most common forms of settlement work are using checks and credit cards. Both forms of settlements are through the system of the federal reserve and the central bank, which monitor the payments using checks and credit cards. The American strategy to combat money laundering can not be called a decent and rational. Despite legislative innovations, we can not say that the federal government has managed to prosecute all illegal transactions with money of dubious origin. In addition, the issue of interaction between law enforcement and controlling bodies is not resolved. So, in the American government's strategy to combat the legalization of criminal proceeds, 10-12 different federal agencies are responsible for different directions of its implementation, and the mechanism of their cooperation is not developed ${ }^{11}$.

Law enforcement officers increasingly have to not only perform functions to combat economic crime and stop the illegal activities, but also to eliminate the consequences of such offenses, to return funds, property and valuables from foreign countries, which is one of the most difficult tasks. The problem is compounded by the weakness of the financial control system in Ukraine and the CIS countries, in which it is virtually impossible to establish the origin of cash, large amounts are in circulation in cash.

Currently, cooperation between law enforcement agencies of Ukraine is in the process of becoming. Few contacts have been maintained with the United Nations, the Organization for Security and Co-operation in Europe, the International Financial Action Task Force on Money Laundering, , The Council of Europe (mainly this is a participation in projects on financing and organizational support of the activities of Ukrainian law-enforcement bodies, which is carried out in the form of conferences, seminars, trainings).

10 Половинський Л.В. Протидія легалізації (відмиванню) доходів, одержаних злочинним шляхом: міжнародний та вітчизняний досвід. Економіка. Фінанси. Право. 2008. № 5. С. 33.

${ }^{11}$ Журавель М.I. Міжнародні правові аспекти боротьби з легалізацією доходів здобутих злочинним шляхом. Часопис Київського університету права. 2010. № 1. С. 283. 
The most effective practical interaction is established with Interpol. Recognizing the high degree of harm caused by economic crimes to society and the world financial system, the Police Directorate of the General Secretariat of Interpol formed a Department for Combating Financial and Economic Crimes, which also includes the ROAS Working Group, which specializes in controlling income received as a result of criminal activity. The research of Flatwash Group is aimed at detecting suspicious financial transactions and money, property and property acquired in a criminal way, as well as in CIS countries ${ }^{12}$. In some states, financial intelligence units have been established that are integrated into the single Egmond network, which aims to intensify the exchange of information on economic crimes, and the creation of a unified international database of such crimes. The main focus is on crimes of money laundering. The modern system of combating economic crime as a result of its development has consolidated the basic rules and principles of interaction between the competent authorities of the world, has developed a unified methodology for requesting information, as well as the amount of information that can be provided. Thus, during operational and investigative measures and investigative actions related to the disclosure of crimes in the field of economy, the channels of Interpol, you can receive the following information: official names of commercial structures (firms, organizations); the date of registration of legal entities and business entities in state bodies; legal address, telephones and other telecommunication facilities; surnames and names of heads of such structures; main directions of activity of the enterprise; the size of the authorized capital; information about termination of activity; criminal records concerning the heads of enterprises. Along with the achievements of law enforcement agencies in combating crime, many problems remain, in particular, with regard to extradition (extradition) of persons who committed economic crimes, from one state to another. For example, almost all agreements concluded by Ukraine exclude crimes in the field of economic activity or financial violations. First of all, this is done to prevent abuse by governments of individual countries, who, in the guise of pursuit of economic crimes,

12 Мартинов М.Д. Сучасні проблеми організації діяльності органів внутрішніх справ України та шляхи їх вирішення. Форум права. 2010. № 3. С. 290-296. URL: http://www. nbuv. gov.ua/ejournals/FP/2010-3/10mmdsiv.pdf 
pursue a person on a political, religious or military basis. Therefore, persons extracted for committing economic crimes may be counted on their fingers.

One of the methods for collecting operational information is the use of open source intelligence, namely, "OSINT" (open-source intelligence). Today, one can observe an increase in interest in OSINT not only by journalists, analysts of private companies and ordinary citizens, but also by intelligence analysts of special services, because OSINT has certain advantages over the collection, processing and analysis of restricted information, on the very fact that does not require special access to information, which means it saves the time of the user, does not require special skills, the cost of significant funds. Using "OSINT" in some cases prevents the commission of a criminal offense, since the expression "It is better to prevent crime than to punish" becomes more and more important.

The United States uses OSINT information to a greater extent for planning combat operations, organizing and conducting military operations, and preventing terrorist acts ${ }^{13}$. According to US intelligence analysts, the biggest problem with OSINT is currently unverified sources of information, provocative resources, insecure information. In order to obtain the most relevant and qualitative information, the user must process a lot of information from different sources and summarize it as required by the purpose and objectives of the study. In the United States, an extensive network of centers and points conducting OSINT intelligence has been formed and provides information to more than 7,000 intelligence data consumers. And this is nothing more than a result of coordinated actions of the legislative and executive authorities aimed at pursuing a focused policy in the field of ensuring national security. Similar structures exist at all levels ${ }^{14}$. Israel also uses "OSINT" primarily to analyze the military capabilities of the enemy. In the military intelligence structure there is a separate special unit for the analysis of

13 Додонов А.Г., Ландэ Д.В., Цыганок В.В. и др. Распознавание информационных операций. К. : ООО «Инжиниринг», 2017. 282 с.; Разведка с использованием открытых источников информации в CША. URL: http://pentagonus.ru/publ/razvedka_s_ispolzovaniem_otkrytykh_istochnikov_ informacii_v_ssha/80-1-0-1614.

14 Разведка с использованием открытых источников информащии в США. URL: $\quad$ http://pentagonus.ru/publ/razvedka_s_ispolzovaniem_otkrytykh_istochnikov_ informacii_v_ssha/80-1-0-1614. 
open sources of information "Hatsaf", which collects information only for military purposes. In the UK, with the help of "OSINT," civilian journalists from the BBC Monitoring Service are collecting primary information, which goes into the secret services for further use in specific research areas. Considering the international experience of using OSINT, it may be noted that a large number of information sources are needed to obtain high-quality and up-to-date information. For correct and productive work of this method it is not enough to find information, it must be processed, analyzed, found confirmation of the investigated facts, events and phenomena, because much information is created just for misinformation. For today in the leading countries of the world "OSINT" is actively and successfully used by information and analytical units; data on the percentage of productivity of open source information confirm the need and relevance of US and European experience in solving operational, tactical and strategic tasks of law enforcement agencies. Since the difference between a newcomer looking for information on the Internet and a OSINT professional who is familiar with the search and analysis technique has some skills in this area, it is enormous: where the novice will see the photo, the number of reposts, groups and pages that the person signed, profile of a person in social networks - the professional will see the activity, the dates of publications, the background in the photographs, the possible reasons for subscribing to certain groups, highlight the circles of communication (build a scheme of connections of the person / persons), etc.

\section{CONCLUSIONS}

Therefore, one can confidently assert that in order to increase the effectiveness of protecting the economic rights, freedoms and interests of individuals during the investigation of criminal offenses, it is considered necessary and expedient to use the whole arsenal of analytical methods. In order to achieve the maximum level of automation of work, qualitative processing and visualization (visibility) of relationships between individuals, events and individuals in the existing large masses of information in the investigation of multiepisode, complex, latent economic crimes committed by organized criminal groups (groups), it is recommended to use standard software criminal analysis, for example, such software systems as IBM I2 Analyst's Notebook, IBM I2 iBase8, and others. The indicated analytical 
tools considerably increase the efficiency of investigating the investigated crimes, due to the possibility of drawing up charts (diagrams) of criminal ties (including telephone communication schemes with unlimited number of mobile phones and numbers), event matrices, financial flow diagrams, frequency charts of contacts.

Today, all law enforcement agencies in developed countries have powerful automated tools for configuring, collecting, controlling, analyzing and displaying complex information and communications, as well as the nature of data. This approach is a requirement of the present for a complete counteraction to organized crime, which makes it possible to simplify the task of criminal proceedings for the protection of economic rights, freedoms and interests of a person, society, the state from criminal offenses, as well as to ensure a prompt, full and impartial investigation so that everyone, Whoever committed a criminal offense has been prosecuted as guilty.

\section{SUMMARY}

This section covers the use of analytical methods to protect economic rights, freedoms and interests of individuals in the investigation of criminal offenses. The position on the place of information analysis in counteracting crime is substantiated. The general directions of analytical activity of law enforcement bodies are indicated. Graphically, the place of system analysis in the structure of analytics and related branches of knowledge is depicted. The experience of the European Union and the United States regarding the use of criminal analysis capabilities in combating economic crime is presented. The directions of use of elements of criminal analysis (specialized software) during investigation of economic criminal offenses are indicated. The indicated analytical tools considerably increase the efficiency of investigating the investigated crimes, due to the possibility of drawing up charts (diagrams) of criminal ties (including telephone communication schemes with unlimited number of mobile phones and numbers), event matrices, financial flow diagrams, frequency charts of contacts.

\section{REFERENCES}

1. Користін О.С., Албул С.В. та ін. Основи кримінального аналізу : посібник з елементами тренінгу. Одеса : ОДУВС, 2016112 с. 
2. Албул С.В. Кримінальна розвідка як функція оперативнорозшукової діяльності: Свропейський досвід та Українські перспективи. European Reforms Bulletin: international scientific peerreviewed journal: Grand Duchy of Luxembourg. 2015. № 2. P. 2-6.

3. Власюк О.В. Роль і місце кримінального аналізу у розкритті та розслідуванні злочинів на державному кордоні України. Матеріали постійно діючого науково-практичного семінару. Х. : Інститут підготовки юрид. кадрів для СБУ Нач. юрид. акад. України ім. Я. Мудрого, 2011. Випуск № 3. Частина № 1. С. 82-85.

4. Beebe, Sarah Miller; Pherson, Randolph H. (2014). Cases in Intelligence Analysis: Structured Analytic Techniques in Action. SAGE Publications.

5. Heuer, Richards J. Jr. (2007). Psychology Intelligence Analysis, Pherson Associates, LLC: Reston, VA. Електронний ресурс. Режим доступу: https://www.cia.gov/csi/books/19104/index.html.

6. Pherson Katherine and Pherson Randolph. (2013) Critical Thinking for Strategic Intelligence. SAGE Publications. Central Intelligence Agency (CIA)

7. Khalsa, S. (2009). Intelligence Community Debate over Intuition versus Structured Technique: Implications for Improving Intelligence Warning. Journal Conflict Studies. Retrieved from http://journals.hil.unb.ca/index.php/JCS/article/view/15234/20838.

8. (2012). A Tradecraft Primer: Structured Analytic Techniques for Improving Intelligence Analysis - Cognitive and Perceptual Biases, Reasoning Processes.

9. Сайтбеков А.М., Кондратьев И.В. Возможности использования аналитических программ в борьбе с организованной преступностью. Вестник КарГу. 2015. URL: http://articlekz.com/ article/11838.

10. Холостенко А.В. Можливості використання аналітичних методик при розслідуванні злочинів, повьязаних із неправомірною вигодою. Кримінальна розвідка: методологія, законодавство, зарубіжний досвід: матеріали Міжнародної науково-практичної конферениії (м. Одеса, 29 квітня 2016 р.). Одеса: ОДУВС, 2016. C. $175-176$.

11. Інструкція про організацію проведення негласних слідчорозшукових дій. URL: http://zakon3.rada.gov.ua/laws/show/ v0114900-12. 
12. Албул С.В. Злочинне середовище та його інфраструктура як об’єкти реалізації розвідувальної функції оперативно-розшукової діяльності органів внутрішніх справ. Процесуальні, криміналістичні та психологічні аспекти досудового розслідування: Матеріали Всеукраӥнської науково-практичної конференції (Одеса, 07 листопада 2014). Одеса: ОДУВС, 2014. С. 29-30.

13. Бандурка O.M., Перепелиця М.M., Манжай O.В. Оперативно-розшукова компаративістика: [монографія]. Харків: ХНУВС, 2013. $352 \mathrm{c}$.

14. Половинський Л.В. Протидія легалізації (відмиванню) доходів, одержаних злочинним шляхом: міжнародний та вітчизняний досвід. Економіка. Фінанси. Право. 2008. № 5. С. 33-35.

15. Журавель М.I. Міжнародні правові аспекти боротьби 3 легалізацією доходів здобутих злочинним шляхом. Часопис Київського університету права. 2010. № 1. С. 280-286.

16. Мартинов М.Д. Сучасні проблеми організації діяльності органів внутрішніх справ України та шляхи їх вирішення. Форум права. 2010. № 3. С. 290-296. URL: http://www.nbuv.gov.ua/ ejournals/FP/2010-3/10mmdsiv.pdf.

17. Додонов А.Г., Ландэ Д.В., Цыганок В.В. и др. Распознавание информационных операций. К. : ООО «Инжиниринг», 2017. 282 с.

18. Разведка с использованием открытых источников информации в США. URL: http://pentagonus.ru/publ/razvedka s_ispolzovaniem_otkrytykh_istochnikov_informacii_v_ssha/80-1-01614 (дата звернення: 29.10.2018).

19. Разведка на основе открытых источников. URL: http://www.in4sec.com.ua/razvedka-na-osnove-otkry-ty-h-istochnikovopen-sourceintelligence-osint/ (дата звернення: 29.10.2018).

\section{Information about the author:} Zaiets O. M.

Candidate of Legal Sciences $(\mathrm{PhD})$, Associate Professor, Head of the Department of Criminology, Forensic Medicine and Psychiatry, Odessa State University of Internal Affairs

1, Uspenska str., Odessa, Ukraine 